\title{
Mineral and trace metal supplement for use with synthetic diets based on comminuted chicken
}

\author{
JANET M. THORN, P. J. AGGETT, H. T. DELVES, AND BARBARA E. CLAYTON \\ From the Department of Chemical Pathology, Institute of Child Health and Hospital for Sick Children, \\ London
}

SUMMARY Earlier studies (Alexander et al., 1974; Lawson et al., 1977) suggested a suitable composition for a mineral and trace metal supplement for use with synthetic diets containing some natural food. Such a mixture has been evaluated in patients receiving a diet based on comminuted chicken and has been shown to be adequate. This conclusion was based on balance experiments measuring $\mathrm{Zn}, \mathrm{Cu}, \mathrm{Mn}, \mathrm{Fe}, \mathrm{Ca}, \mathrm{Mg}, \mathrm{N}$, and $\mathrm{P}$.

A mineral and trace metal mixture (M1) (Aminogran Mineral Mixture, Allen \& Hanburys Ltd, or Metabolic Mineral Mixture, Scientific Hospital Supplies Ltd) used with synthetic diets containing some natural foods for the management of inborn errors of metabolism, was found to be inadequate in $\mathrm{Zn}, \mathrm{Cu}, \mathrm{Fe}$, and $\mathrm{Mn}$ (Alexander et al., 1974). An amended mixture (M2) was formulated and contained a 4-fold increase in the content of $\mathrm{Zn}$, a 2 -fold increase in $\mathrm{Cu}$, and $25 \%$ increase in $\mathrm{Fe} ; \mathrm{Mn}$ was provided separately as tablets $(1.1 \mu \mathrm{mol}$; $60 \mu \mathrm{g}$ ) according to body weight up to a maximum of 6 tablets a day.

Evaluation of M2 in patients with phenylketonuria showed it to be satisfactory for $\mathrm{Zn}, \mathrm{Cu}$, and Fe. A minor change was suggested for $\mathrm{Mn}$ (Lawson et al., 1977), and this modification was incorporated into a 3rd mixture (M3).

Received 16 March 1978
For several years the mineral mixture M1 had been used to supplement a synthetic diet based on comminuted chicken (Cow \& Gate Ltd). This is used to treat children with food intolerances and malabsorption for whom milk-, lactose-, and sucrosefree diets are required (Larcher et al., 1977). The patients are often less than one-year old and receive little, if any, natural foods apart from chicken.

Such patients are considered to be at risk from an inadequate intake of minerals and trace metals because of their age, dietary restrictions, and malabsorptive states. A study was designed to evaluate the adequacy of M2 and M3 compared with M1, as supplements to this diet.

The compositions of M1, M2, and M3 are given in Table 1. The results for balances with M1 and M3 are combined as there is no significant difference in their composition.

$1.5 \mathrm{~g}$ of mixture $/ \mathrm{kg}$ body weight is added to the feed, up to a maximum of $8 \mathrm{~g}$ daily.

Table 1 Composition of mineral and trace metal supplements (per $\mathrm{kg}$ )

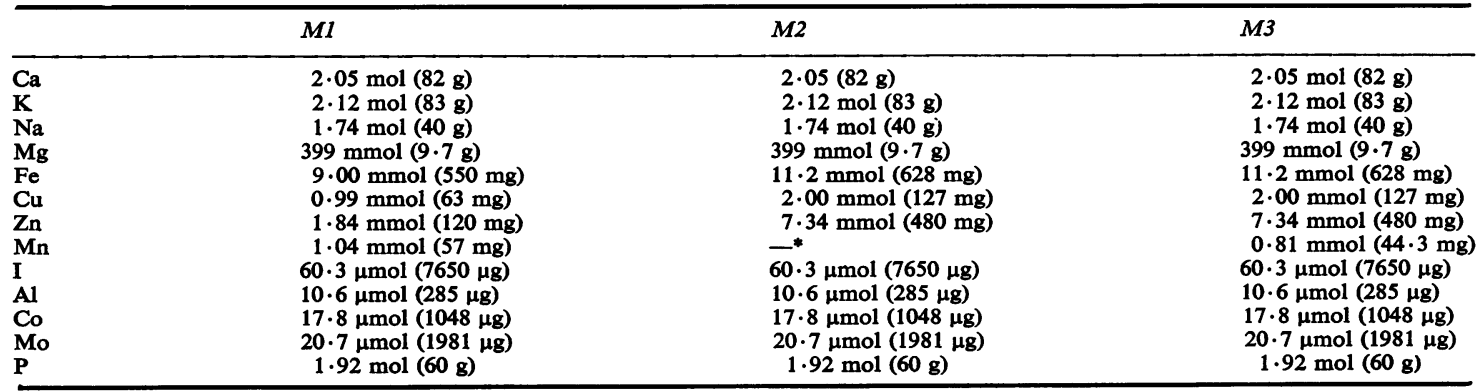

* Manganese administered in tablets, each containing $1.1 \mu \mathrm{mol}(60 \mu \mathrm{g})$.

These mixtures were prepared from simple salts of the metals shown, i.e. chloride, sulphate, and phosphate together with lactate as diluent. 


\section{Patients and methods}

Metabolic balances were performed on 4 patients aged between 0.16 and 1.53 years who had been on the comminuted chicken diet for at least 3 weeks. Their clinical details are summarised in Table 2. There was a steady weight gain in each, which began before the first balance and was maintained during both studies and in the intervening period. In 3 of them (Cases 1, 3, and 4) the number of stools passed was greater on M2/M3 than on M1, and the other patient (Case 2) passed the same number of stools on both balances.

The diet was based on comminuted chicken as the source of protein with additional fat, carbohydrate, and vitamins as described by Larcher $e t$ al. (1977). Details of small amounts of additional solids which were milk-, lactose-, sucrose-, and gluten-free, and of medicines, including iron supplements, are shown in Table 3. Additional supplements of $\mathrm{Ca}$ (as $\mathrm{Ca}$ gluconate) were given to babies receiving less than the recommended $12.1 \mathrm{mmol}$ (500 mg) Ca per day.

Balance studies. Three-day balance studies were performed twice on each child, first on M1 and then on M2, with the exception of Case 4 who received M3 for his 2nd balance. Case 3 had increased her body weight considerably while at home and received only two-thirds of the correct dose of M2 and manganese tablets as there was no time to equilibrate her on the correct dose before balancing.

Conventional balance techniques were used, with faeces and urine being collected on to deionised nappies (Alexander and Delves, 1972). Analyses of $\mathrm{Zn}, \mathrm{Cu}, \mathrm{Mn}, \mathrm{Fe}, \mathrm{Ca}, \mathrm{Mg}, \mathrm{N}$, and $\mathrm{P}$ were performed as described previously (Alexander et al., 1974).

\section{Results}

Although urine and faeces were analysed separately there was some contamination between them. Mean daily totals and totals $/ \mathbf{k g}$ were calculated for the intake, excretion, absorption, and retention of each element on M1 and M2/M3, and the results are shown in Tables 4 and 5. Daily intake was plotted against body weight and regression lines were calculated (Figs 1 to 7, odd numbers). Intake/kg per day was plotted against excretion/kg per day to indicate the net overall balance (Figs 2 to 8, even numbers).

As each child acted as his/her own control, retentions per $\mathrm{kg}$ each day on $\mathrm{M} 1$ and $\mathrm{M} 2 / \mathrm{M} 3$ were compared using a paired $t$ test. Percentage absorptions and retentions are shown in Table 6.

Table 2 Details of patients receiving synthetic diets on comminuted chicken

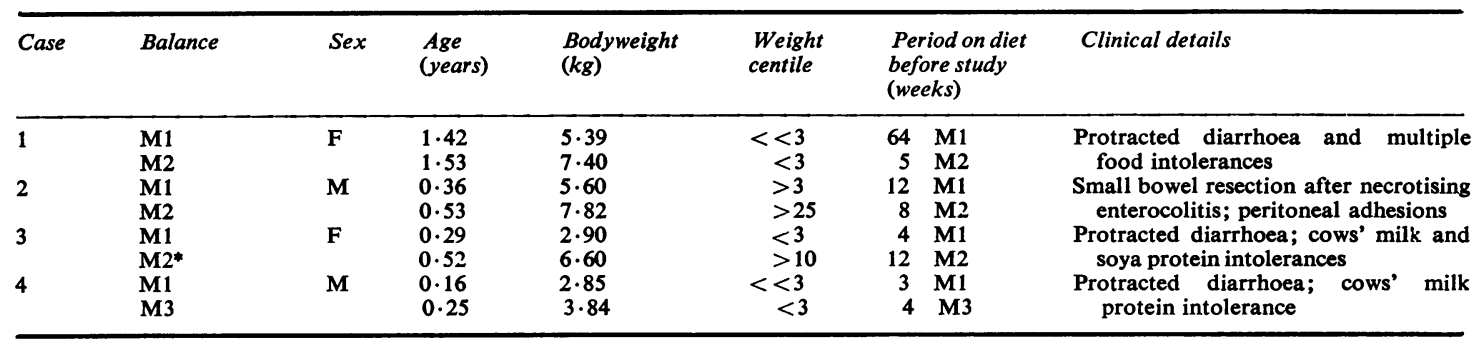

*Received two-thirds of the correct dose of mineral mixture and manganese tablets.

Table 3 Details of diets and medicines

\begin{tabular}{|c|c|c|c|c|}
\hline Case & Balance & Iron supplements & $\begin{array}{l}\text { Solids in addition to } \\
\text { chicken formula }\end{array}$ & Medicines \\
\hline 1 & $\begin{array}{l}\text { M1 } \\
\text { M2 }\end{array}$ & $\begin{array}{l}\text { Yes } \\
\text { No }\end{array}$ & $\begin{array}{l}\text { RBR, chicken, potato } \\
\text { RBR, chicken, potato }\end{array}$ & $\begin{array}{l}\text { Sytron } \ddagger \text {, Ketovite } \S \S \text { tablets + liquid, metoclopramide } \\
\text { Ketovite tablets + liquid, metoclopramide }\end{array}$ \\
\hline 2 & $\begin{array}{l}\text { M1 } \\
\text { M2 }\end{array}$ & $\begin{array}{l}\text { Stopped prebalance } \\
\text { No }\end{array}$ & $\begin{array}{l}\text { RBR } \\
\text { RBR, puréed savoury }\end{array}$ & $\begin{array}{l}\text { Ketovite tablets + liquid } \\
\text { Ketovite tablets + liquid }\end{array}$ \\
\hline 3 & M1† & $\begin{array}{l}\text { Stopped prebalance } \\
\text { No }\end{array}$ & $\begin{array}{l}\text { None } \\
\text { None }\end{array}$ & $\begin{array}{l}\text { Ketovite tablets + liquid, metoclopramide, folic acid, nystatin } \\
\text { Ketovite tablets + liquid, folic acid }\end{array}$ \\
\hline 4 & $\begin{array}{l}\text { M1† } \\
\text { M3 }\end{array}$ & $\begin{array}{l}\text { Yes } \\
\text { Yes }\end{array}$ & $\begin{array}{l}\text { None } \\
\text { None }\end{array}$ & $\begin{array}{l}\text { Ketovite tablets }+ \text { liquid, ferrous sulphate } \\
\text { Ketovite tablets + liquid, ferrous sulphate }\end{array}$ \\
\hline
\end{tabular}

* Received two-thirds only of the correct dose of mixture and manganese tablets; †received additional calcium gluconate in feeds (see text). †Sodium iron edetate (Parke Davies \& Co.); §§Paines \& Byrne Ltd. RBR=Robinson's baby rice. 
Table 4 Synthetic diet based on comminuted chicken: metabolic balances. Mean intake and excretion of elements (units/kg per day $\pm S D$ )

\begin{tabular}{|c|c|c|c|c|c|c|c|}
\hline \multirow{2}{*}{ Element } & \multirow{2}{*}{$\begin{array}{l}\text { Mineral } \\
\text { supplement }\end{array}$} & \multirow{2}{*}{ Intake } & \multicolumn{3}{|l|}{ Excretion } & \multirow{2}{*}{ Absorbed } & \multirow{2}{*}{ Retained } \\
\hline & & & Total & Urine & Faeces & & \\
\hline $\mathrm{Zn}(\mu \mathrm{mol})$ & $\begin{array}{l}\text { M1 } \\
\text { M2/M3 }\end{array}$ & $\begin{array}{r}5.97 \pm 0.94 \\
11 \cdot 56 \pm 3.60\end{array}$ & $\begin{array}{l}7.84 \pm 1.05 \\
9.23 \pm 3.63\end{array}$ & $\begin{array}{l}1.79 \pm 0.38 \\
1.58 \pm 0.98\end{array}$ & $\begin{array}{l}6.05 \pm 1.05 \\
7.65 \pm 2.83\end{array}$ & $\begin{array}{r}-0.08 \pm 1.00 \\
3.91 \pm 2.02\end{array}$ & $\begin{array}{r}-1.87 \pm 0.34 \\
2.33 \pm 1.91\end{array}$ \\
\hline $\mathrm{Cu}(\mu \mathrm{mol})$ & $\begin{array}{l}\text { M1 } \\
\text { M2/M3 }\end{array}$ & $\begin{array}{l}1.73 \pm 0.35 \\
2.23 \pm 0.63\end{array}$ & $\begin{array}{l}1.39 \pm 0.33 \\
1.72 \pm 0.54\end{array}$ & $\begin{array}{l}0.06 \pm 0.02 \\
0.13 \pm 0.02\end{array}$ & $\begin{array}{l}1.33 \pm 0.31 \\
1.59 \pm 0.54\end{array}$ & $\begin{array}{l}0.40 \pm 0.50 \\
0.64 \pm 0.34\end{array}$ & $\begin{array}{l}0.34 \pm 0.51 ! \\
0.51 \pm 0.35\end{array}$ \\
\hline $\mathrm{Mn}(\mu \mathrm{mol})$ & $\begin{array}{l}\text { M1 } \\
\text { M2/M3 }\end{array}$ & $\begin{array}{l}1.71 \pm 0.35 \\
1.51 \pm 0.60\end{array}$ & $\begin{array}{l}1.52 \pm 0.37 \\
1.24 \pm 0.49\end{array}$ & $\begin{array}{l}0.03 \pm 0.04 \\
0.04 \pm 0.03\end{array}$ & $\begin{array}{l}1.49 \pm 0.35 \\
1.20 \pm 0.48\end{array}$ & $\begin{array}{l}0.22 \pm 0.23 \\
0.31 \pm 0.23\end{array}$ & $\begin{array}{l}0.19 \pm 0.27 \\
0.27 \pm 0.24\end{array}$ \\
\hline $\mathrm{Ca}(\mathrm{mmol})$ & $\begin{array}{l}\text { M1 } \\
\text { M2/M3 }\end{array}$ & $\begin{array}{l}3.43 \pm 0.46 \\
2.53 \pm 0.62\end{array}$ & $\begin{array}{l}2 \cdot 78 \pm 1.00 \\
1 \cdot 48 \pm 0.34\end{array}$ & $\begin{array}{l}0.12 \pm 0.07 \\
1.23 \pm 0.03\end{array}$ & $\begin{array}{l}2.66 \pm 0.95 \\
1.36 \pm 0.32\end{array}$ & $\begin{array}{l}0.77 \pm 0.65 \\
1.17 \pm 0.46\end{array}$ & $\begin{array}{l}0.65 \pm 0.69 \\
1.05 \pm 0.48\end{array}$ \\
\hline $\mathbf{M g}$ (mmol) & $\begin{array}{l}\text { M1 } \\
\text { M2/M3 }\end{array}$ & $\begin{array}{l}0.94 \pm 0.08 \\
0.80 \pm 0.18\end{array}$ & $\begin{array}{l}0.74 \pm 0.12 \\
0.60 \pm 0.16\end{array}$ & $\begin{array}{l}0.11 \pm 0.07 \\
0.16 \pm 0.04\end{array}$ & $\begin{array}{l}0.63 \pm 0.06 \\
0.44 \pm 0.16\end{array}$ & $\begin{array}{l}0.30 \pm 0.02 \\
0.36 \pm 0.05\end{array}$ & $\begin{array}{l}0.19 \pm 0.07 \\
0.20 \pm 0.08\end{array}$ \\
\hline $\mathrm{N}(\mathrm{mmol})$ & $\begin{array}{l}\text { M1 } \\
\text { M2/M3 }\end{array}$ & $\begin{array}{l}90 \cdot 40 \pm 10 \cdot 60 \\
79 \cdot 40 \pm 18 \cdot 30\end{array}$ & $\begin{array}{l}51 \cdot 50 \pm 8 \cdot 70 \\
48 \cdot 50 \pm 9 \cdot 10\end{array}$ & $\begin{array}{l}30 \cdot 10 \pm 10 \cdot 10 \\
31 \cdot 20 \pm 5 \cdot 60\end{array}$ & $\begin{array}{l}21 \cdot 40 \pm 10 \cdot 90 \\
17 \cdot 30 \pm 8 \cdot 30\end{array}$ & $\begin{array}{l}69 \cdot 00 \pm 10 \cdot 10 \\
62 \cdot 10 \pm 12 \cdot 20\end{array}$ & $\begin{array}{l}38 \cdot 90 \pm 2 \cdot 20 \\
30 \cdot 90 \pm 11 \cdot 30\end{array}$ \\
\hline$P(\mathrm{mmol})$ & $\begin{array}{l}\text { M1 } \\
\text { M2/M3 }\end{array}$ & $\begin{array}{l}3.98 \pm 0.66 \\
3.78 \pm 0.94\end{array}$ & $\begin{array}{l}2 \cdot 63 \pm 0.50 \\
2 \cdot 27 \pm 0.35\end{array}$ & $\begin{array}{l}1.05 \pm 0.65 \\
1.33 \pm 0.51\end{array}$ & $\begin{array}{l}1.58 \pm 0.46 \\
0.94 \pm 0.41\end{array}$ & $\begin{array}{l}2.40 \pm 0.79 \\
2.84 \pm 0.83\end{array}$ & $\begin{array}{l}1.35 \pm 0.22 \\
1.51 \pm 0.71\end{array}$ \\
\hline
\end{tabular}

*Differences in retention with M1 compared with M2/M3: $P=0.02$.

Conversion: SI to traditional units- $\mathrm{Zn}: 1 \mu \mathrm{mol} \approx 65.4 \mu \mathrm{g} ; \mathrm{Cu}: 1 \mu \mathrm{mol} \approx 63.5 \mu \mathrm{g} ; \mathrm{Mn}: 1 \mu \mathrm{mol} \approx 54.9 \mu \mathrm{g} ; \mathrm{Ca}: 1 \mathrm{mmol} \approx 40 \cdot 1 \mathrm{mg} ; \mathrm{Mg}: 1$ $\mathrm{mmol} \approx 24 \cdot 3 \mathrm{mg} ; \mathrm{P}: 1 \mathrm{mmol} \approx 31 \mathrm{mg} ; \mathrm{N}: 1 \mathrm{mmol} \approx 14 \mathrm{mg}$.

Table 5 Mean total intake and retention of elements per day $\pm S D$

\begin{tabular}{|c|c|c|c|c|c|}
\hline \multirow{2}{*}{ Element } & \multirow{2}{*}{ Supplement } & \multicolumn{2}{|l|}{ Intake } & \multicolumn{2}{|c|}{ Retention } \\
\hline & & Mean & $\pm S D$ & Mean & $=S D$ \\
\hline $\mathrm{Zn}(\mu \mathrm{mol})$ & $\begin{array}{l}\text { M1 } \\
\text { M2/M3 }\end{array}$ & $\begin{array}{l}25 \cdot 5 \\
73 \cdot 3\end{array}$ & $\begin{array}{l}11 \cdot 7 \\
31 \cdot 7\end{array}$ & $\begin{array}{r}-7 \cdot 4 \\
16 \cdot 3\end{array}$ & $\begin{array}{r}2.5 \\
15.4\end{array}$ \\
\hline $\mathrm{Cu}(\mu \mathrm{mol})$ & $\begin{array}{l}\text { M1 } \\
\text { M2/M3 }\end{array}$ & $\begin{array}{r}7 \cdot 1 \\
13 \cdot 8\end{array}$ & $\begin{array}{l}2 \cdot 1 \\
4 \cdot 0\end{array}$ & $\begin{array}{l}1.6 \\
3.4\end{array}$ & $\begin{array}{l}1 \cdot 7 \\
2 \cdot 8\end{array}$ \\
\hline Mn ( $\mu \mathrm{mol})$ & $\begin{array}{l}\text { M1 } \\
\text { M2/M3 }\end{array}$ & $\begin{array}{r}7 \cdot 5 \\
10 \cdot 0\end{array}$ & $\begin{array}{l}4.0 \\
6.0\end{array}$ & $\begin{array}{l}1.0 \\
2.0\end{array}$ & $\begin{array}{l}1.2 \\
1.9\end{array}$ \\
\hline $\mathrm{Ca}(\mathrm{mmol})$ & $\begin{array}{l}\text { M1 } \\
\text { M2/M3 }\end{array}$ & $\begin{array}{l}14 \cdot 2 \\
15 \cdot 9\end{array}$ & $\begin{array}{l}5 \cdot 3 \\
5 \cdot 4\end{array}$ & $\begin{array}{l}3 \cdot 3 \\
6 \cdot 7\end{array}$ & $\begin{array}{l}3 \cdot 5 \\
3.9\end{array}$ \\
\hline $\mathbf{M g}(\mathrm{mmol})$ & $\begin{array}{l}\text { M1 } \\
\text { M2/M3 }\end{array}$ & $\begin{array}{l}3.9 \\
5.0\end{array}$ & $\begin{array}{l}1.4 \\
1.4\end{array}$ & $\begin{array}{l}0.8 \\
1.3\end{array}$ & $\begin{array}{l}0.5 \\
0.7\end{array}$ \\
\hline $\mathbf{N}(\mathrm{mmol})$ & $\begin{array}{l}\text { M1 } \\
\text { M2/M3 }\end{array}$ & $\begin{array}{l}371 \\
497\end{array}$ & $\begin{array}{l}116 \\
148\end{array}$ & $\begin{array}{l}160 \\
196\end{array}$ & $\begin{array}{l}51 \\
93\end{array}$ \\
\hline $\mathbf{P}(\mathrm{mmol})$ & $\begin{array}{l}\text { M1 } \\
\text { M2/M3 }\end{array}$ & $\begin{array}{l}16 \cdot 9 \\
23 \cdot 7\end{array}$ & $\begin{array}{l}7 \cdot 7 \\
7 \cdot 8\end{array}$ & $\begin{array}{l}5.8 \\
9.4\end{array}$ & $\begin{array}{l}2 \cdot 7 \\
4.9\end{array}$ \\
\hline
\end{tabular}

Table 6 Comparison of percentage absorption and retention of elements on $M 1$ and $M 2 / M 3$

\begin{tabular}{|c|c|c|c|}
\hline Element & Supplement & Absorption (\%) & Retention $(\%)$ \\
\hline $\mathbf{Z n}$ & $\begin{array}{l}\text { M1 } \\
\text { M2/M3 }\end{array}$ & $\begin{array}{r}-1 \cdot 9 \\
33 \cdot 3\end{array}$ & $\begin{array}{r}-31.9 \\
20 \cdot 1\end{array}$ \\
\hline $\mathbf{C u}$ & $\begin{array}{l}\text { M1 } \\
\text { M2/M3 }\end{array}$ & $\begin{array}{l}20 \cdot 8 \\
28.4\end{array}$ & $\begin{array}{l}17 \cdot 2 \\
22 \cdot 0\end{array}$ \\
\hline $\mathbf{M n}$ & $\begin{array}{l}\text { M1 } \\
\text { M2/M3 }\end{array}$ & $\begin{array}{l}12 \cdot 8 \\
19 \cdot 7\end{array}$ & $\begin{array}{l}11.0 \\
16.7\end{array}$ \\
\hline $\mathrm{Ca}$ & $\begin{array}{l}\text { M1 } \\
\text { M2/M3 }\end{array}$ & $\begin{array}{l}32 \cdot 2 \\
45 \cdot 2\end{array}$ & $\begin{array}{l}20 \cdot 3 \\
40 \cdot 1\end{array}$ \\
\hline $\mathbf{M g}$ & $\begin{array}{l}\text { M1 } \\
\text { M2/M3 }\end{array}$ & $\begin{array}{l}32.4 \\
45.8\end{array}$ & $\begin{array}{l}21 \cdot 0 \\
24 \cdot 4\end{array}$ \\
\hline $\mathbf{N}$ & $\begin{array}{l}\text { M1 } \\
\text { M2/M3 }\end{array}$ & $\begin{array}{l}76.4 \\
79.0\end{array}$ & $\begin{array}{l}43.7 \\
37.5\end{array}$ \\
\hline $\mathbf{P}$ & $\begin{array}{l}\text { M1 } \\
\text { M2/M3 }\end{array}$ & $\begin{array}{l}59.6 \\
75.2\end{array}$ & $\begin{array}{l}34 \cdot 1 \\
38 \cdot 0\end{array}$ \\
\hline
\end{tabular}

\section{Discussion}

Zinc. The 4 children were in negative $\mathrm{Zn}$ balance when receiving M1 (mean retention $-31.9 \%$ ) but in positive balance on M2/M3 (mean retention $20.1 \%$ ) (Table 6), i.e. retentions of $-1.87 \mu \mathrm{mol}$ $(122 \mu \mathrm{g}) / \mathrm{kg}$ per day (M1) increasing to $+2 \cdot 33 \mu \mathrm{mol}$ $(150 \mu \mathrm{g}) / \mathrm{kg}$ per day $(\mathrm{M} 2 / \mathrm{M} 3)$. Fig. 1 shows the

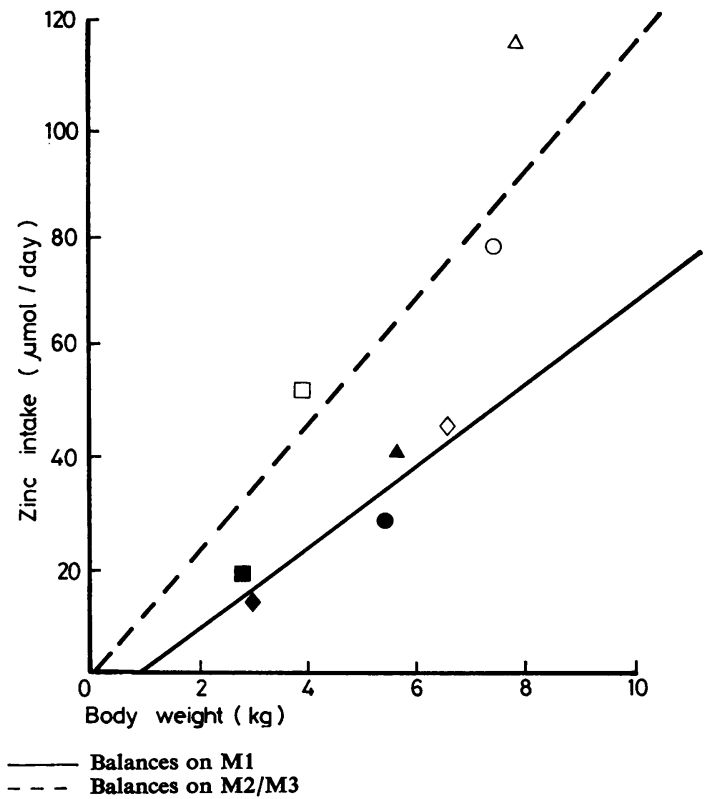

See footnote to Table 4 for conversions.

Fig. 1 Daily zinc intake v. weight. 


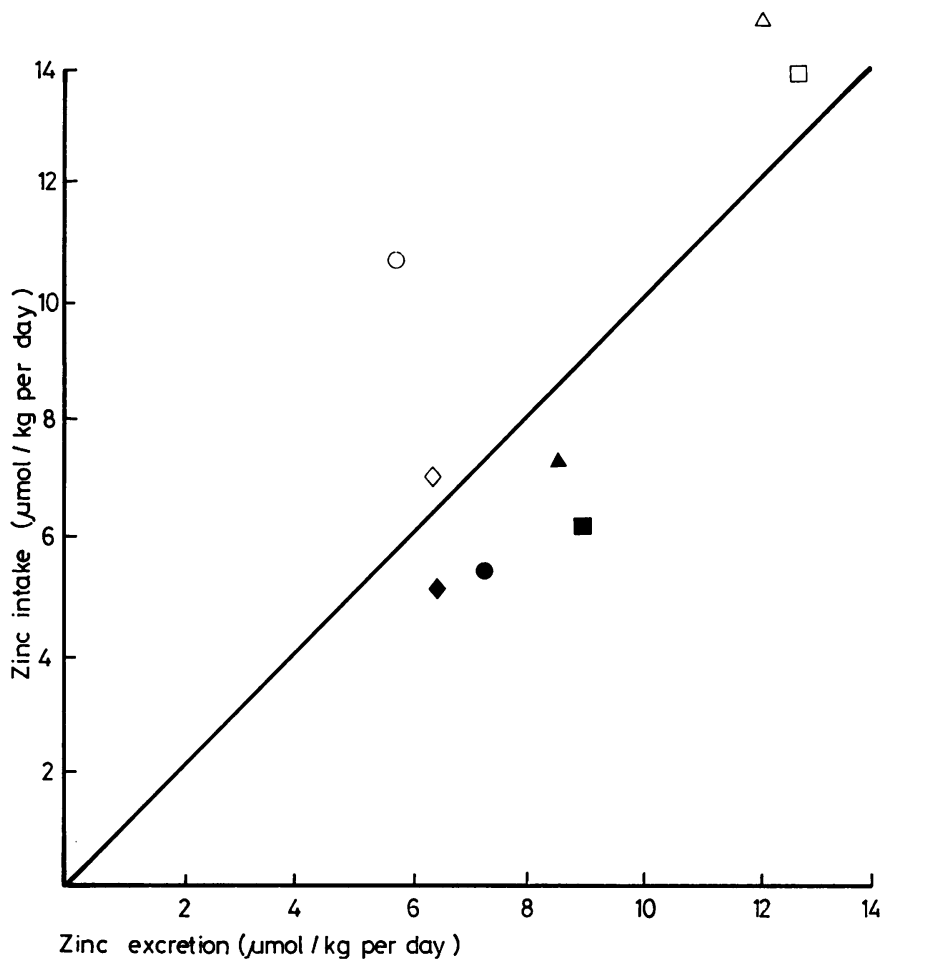

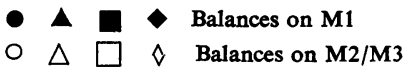

Fig. 2 Daily zinc balance. dietary intake plotted against body weight; the intake increased from a mean of $25.5 \mu \mathrm{mol}(1.7 \mathrm{mg}) /$ day on $\mathrm{M} 1$ to $73 \mu \mathrm{mol}(4.8 \mathrm{mg}) /$ day on $\mathrm{M} 2 / \mathrm{M} 3$, equivalent to an increase from $5.97 \mu \mathrm{mol}(390 \mu \mathrm{g}) / \mathrm{kg}$ per day on M1 to $11.56 \mu \mathrm{mol}(756 \mu \mathrm{g}) / \mathrm{kg}$ per day on M2/M3. This was accounted for by a 4-fold increase in the $\mathrm{Zn}$ content of $\mathrm{M} 2 / \mathrm{M} 3$, and in addition the chicken itself provided approximately $60 \%$ of the $\mathrm{Zn}$ intake from the chicken mixture with $\mathrm{M} 1$, and $30 \%$ with M2/M3. The differences in intakes on the two mixtures can be seen from the regression lines in Fig. 1. The correlation coefficients for these lines were 0.93 (M1) and 0.65 (M2/M3).

The $73 \mu \mathrm{mol} /$ day that our patients received on M2/M3 was comparable with the 45 to $77 \mu \mathrm{mol}$ ( 3 to $5 \mathrm{mg}$ ) and 57 to $82 \mu \mathrm{mol}(3.7$ to $5.3 \mathrm{mg}$ ) per day recommended by the National Research Council Food and Nutrition Board (1974) and World Health Organisation (1973) respectively. (The latter figures were calculated on the basis of $30 \%$ absorption.) Our patients on M1 received a mean of only $25.5 \mu \mathrm{mol}$ per day.

It was concluded that the $\mathrm{Zn}$ content of M2/M3 is adequate for use as a supplement with this diet but that M1 provided an inadequate intake.
Copper. For the 4 patients the mean retention increased from $0.34 \mu \mathrm{mol}(21.6 \mu \mathrm{g}) / \mathrm{kg}$ per day on M1 to $0.51 \mu \mathrm{mol}(32.4 \mu \mathrm{g}) / \mathrm{kg}$ per day on M2/M3 but the difference was not significant. In Case 4 the balance status changed from $-23 \%$ retention on M1 to $+16 \%$ on $\mathrm{M} 3$ and, in Case 1 , the increase was from

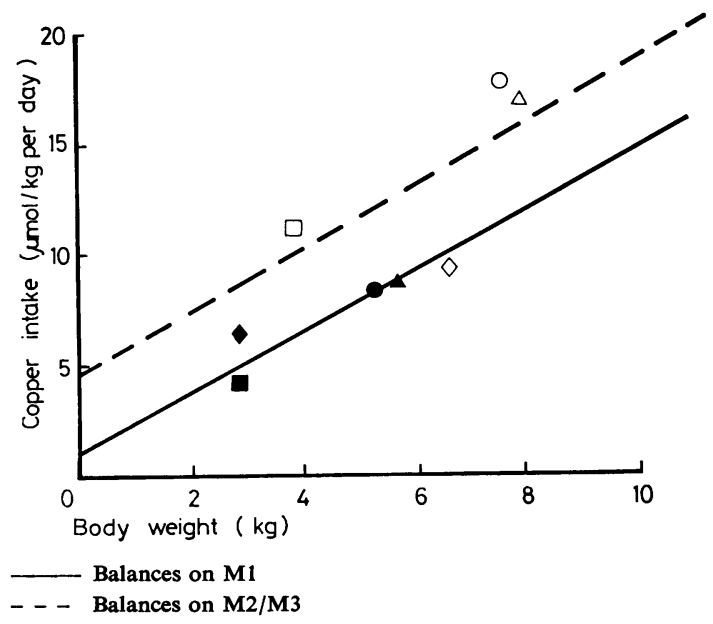

Fig. 3 Daily copper intake v. weight. 


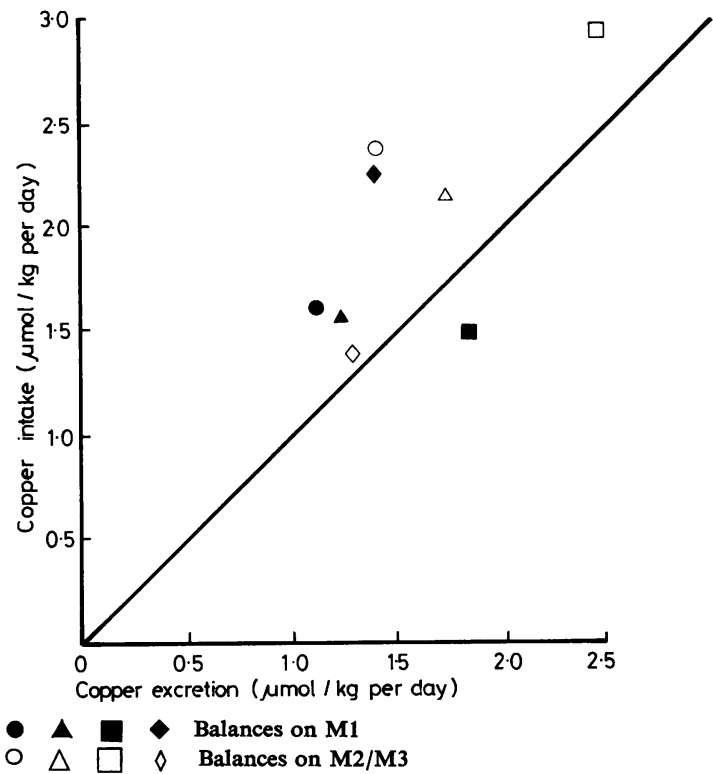

Fig. 4 Daily copper balance.

$31 \%$ (M1) to $41 \%$ (M2) (Table 6). Fig. 3 shows $\mathrm{Cu}$ intake plotted against body weight and indicates the increased $\mathrm{Cu}$ intake on M2/M3. The correlation coefficients for the regression lines were 0.91 and 0.63 for balances on M1 and M2/M3 respectively.

The mean dietary intake of $\mathrm{Cu}$ was $1.73 \mu \mathrm{mol}$ $(110 \mu \mathrm{g}) / \mathrm{kg}$ per day on M1 increasing to $2 \cdot 23 \mu \mathrm{mol}$ $(142 \mu \mathrm{g}) / \mathrm{kg}$ per day with the higher $\mathrm{Cu}$ content of M2/M3 (Table 4). The recommended intake for $\mathrm{Cu}$ was estimated at $1.3 \mu \mathrm{mol}(83 \mu \mathrm{g}) / \mathrm{kg}$ per day for infants and young children (World Health Organisation, 1973), and the National Research Council Food and Nutrition Board (1974) suggested between 0.8 to $1.6 \mu \mathrm{mol}(50$ to $100 \mu \mathrm{g}) / \mathrm{kg}$ per day so that our children were already receiving more than the recommended intake even on M1 (see Fig. 3). However, Cordano et al. (1966) showed that infants with severe marasmus and chronic diarrhoea had depleted $\mathrm{Cu}$ stores which could be corrected by $\mathrm{Cu}$ supplements of at least $2.36 \mu \mathrm{mol}(150 \mu \mathrm{g}) / \mathrm{kg}$ per day. Furthermore, the children in our study were growing faster than normal and were suffering from malabsorption so one would expect the $\mathrm{Cu}$ requirement to be greater than normal.

Toxicity from an excess intake of $\mathrm{Cu}$ is unlikely; the Joint Food and Agriculture Organisation/ World Health Organisation Food Additives Expert Committee suggested that no deleterious effects in adults should be found up to $8 \mu \mathrm{mol}(0.5 \mathrm{mg}) / \mathrm{kg}$ per day (FAO/WHO, 1972). The regulatory mechanism for $\mathrm{Cu}$ appears to be excretion in the bile (van Ravesteyn, 1944).
Manganese. All children were in positive $\mathrm{Mn}$ balance, except Case 4, while receiving M1 (-12\% retention). There was no significant difference between the retentions on M1 compared with M2/ M3 (means 0.19 $\mu \mathrm{mol}(10.4 \mu \mathrm{g}) / \mathrm{kg}$ per day $(11.0 \%)$, and $0.27 \mu \mathrm{mol}(14.8 \mu \mathrm{g}) / \mathrm{kg}$ per day $(16.7 \%)$ respectively (Tables 4 and 6)).

Normal intake of Mn by infants under 6 months was calculated by McLeod and Robinson (1972) to

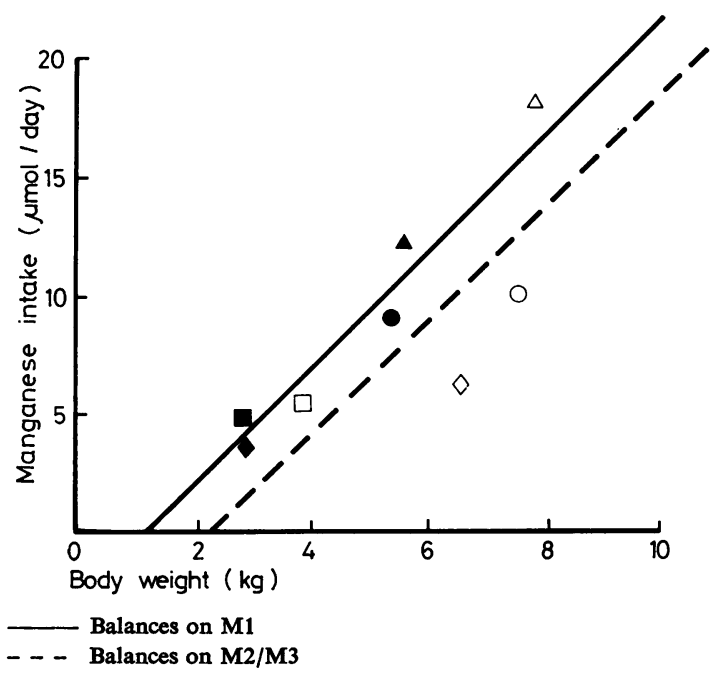

Fig. 5 Daily manganese intake $v$. weight.

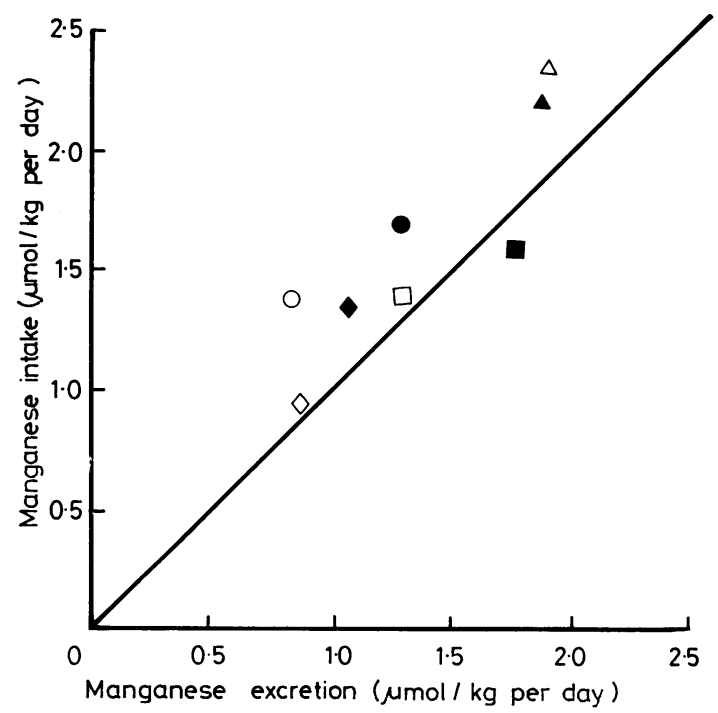

- $\Delta \longrightarrow$ Balances on M1

$\circ \Delta \square \diamond$ Balances on M2/M3

Fig. 6 Daily manganese balance. 
be between 0.05 to $1.37 \mu \mathrm{mol}(2.7$ to $75.2 \mu \mathrm{g}) / \mathrm{kg}$ per day, increasing as more solid foods were introduced into the child's diet. World Health Organisation (1973) give the intake of $\mathrm{Mn}$ by one- to 3year-old children as 2.7 to $3.6 \mu \mathrm{mol}(148$ to $198 \mu \mathrm{g}) /$ $\mathrm{kg}$ per day. In this present study the mean intake of Mn was $1.7 \mu \mathrm{mol}(93 \mu \mathrm{g}) / \mathrm{kg}$ per day on M1 and $1.5 \mu \mathrm{mol}(82 \mu \mathrm{g}) / \mathrm{kg}$ per day on M2/M3.

Mn was incorporated into the original mineral mixture M1, at an amount equivalent to $1.6 \mu \mathrm{mol}$ $(88 \mu \mathrm{g}) / \mathrm{kg}$ per day for young infants up to a maximum of $8.3 \mu \mathrm{mol}(456 \mu \mathrm{g})$ daily (for all children over $5.3 \mathrm{~kg}$ ). Younger patients in the study by Alexander et al. (1974) received an adequate Mn intake on this mixture, but the older patients received significantly less $\mathrm{Mn}$ than healthy children of a similar age, probably due to a lower intake of natural foods.

With M2 it was suggested that Mn should be given as one tablet of $1.1 \mu \mathrm{mol} / \mathrm{kg}$ body weight up to a maximum of 6 tablets daily. This alteration in composition results in a slightly lower intake of Mn by these younger children (Fig. 5). However, all the infants in this study appear to be receiving an adequate amount of $\mathrm{Mn}$ from M2 and remained in positive balance (Fig. 6).

It is therefore recommended that the formulation of M2/M3 as suggested by Lawson et al. (1977) of $6.6 \mu \mathrm{mol}(360 \mu \mathrm{g})$ in $8 \mathrm{~g}$ mixture is suitable as a supplement for these children.

Iron. M1 and M2/M3 were designed to provide an adequate $\mathrm{Fe}$ intake. However, $\mathrm{Fe}$ supplements were being given to all the children before the first balance studies (M1) as part of their medical treatment and, in two, it was not considered ethical to withhold these for the purposes of the investigations. This makes the interpretation of our data difficult. Of the 3 balances during which no $\mathrm{Fe}$ supplements were given (all on M2) all children showed a positive retention of $\mathrm{Fe}(29 \%, 37 \%$, and $8 \%)$. The two with the higher retentions were receiving considerable additional $\mathrm{Fe}$ from solids. The maximum dose of M2 provides $90 \mu \mathrm{mol}(5 \mathrm{mg})$ per day and some additional $\mathrm{Fe}$ is provided by the chicken. The supplements did not appear to affect absorption of other elements. Patient 4 was on additional $\mathrm{Fe}$ during both his 1 st and 2 nd balances but the changes in absorption and retention of the other elements were similar to those observed in the other children.

Calcium and magnesium. The $\mathrm{Ca}$ and $\mathrm{Mg}$ content of M2/M3 remained the same as that of M1, since these two elements were found by Alexander et al. (1974) to be provided in adequate amounts in the original mixture.
All the children in this study were in positive $\mathbf{M g}$ balance and all except one child were in positive Ca balance (Case 4 on M1 showed $-9 \%$ retention). As expected, there was no significant difference between the retentions of $\mathrm{Ca}$ and $\mathrm{Mg}$ when the children were receiving $\mathrm{M} 1$ or $\mathrm{M} 2 / \mathrm{M} 3$.

All the children studied were offered at least the recommended daily intake of $12.5 \mathrm{mmol} \mathrm{Ca}$, although the actual measured intakes were slightly lower than this in some cases due to rejection of food. The mean intakes of $\mathrm{Mg}$ were $3.9 \mathrm{mmol}$ (95 mg) per day (on M1) and $5.00 \mathrm{mmol}(122 \mathrm{mg}$ ) per day (on M2/M3) (Table 4). World Health Organisation (1973) recommended at least 1.6 to $2.9 \mathrm{mmol}(40$ to $70 \mathrm{mg}$ ) per day for children under one-year old and $4.1 \mathrm{mmol}(100 \mathrm{mg})$ for those between 1 and 2 years.

Nitrogen. During both studies all children received similar nitrogen intakes (Fig. 7) and were in positive nitrogen balance (Fig. 8); there was no significant difference between absorption and retention of $\mathbf{N}$ during the 1 st and 2 nd balances. The mean dietary intake of $\mathrm{N}(90.4 \mathrm{mmol}(1.3 \mathrm{~g})$ and 79.4

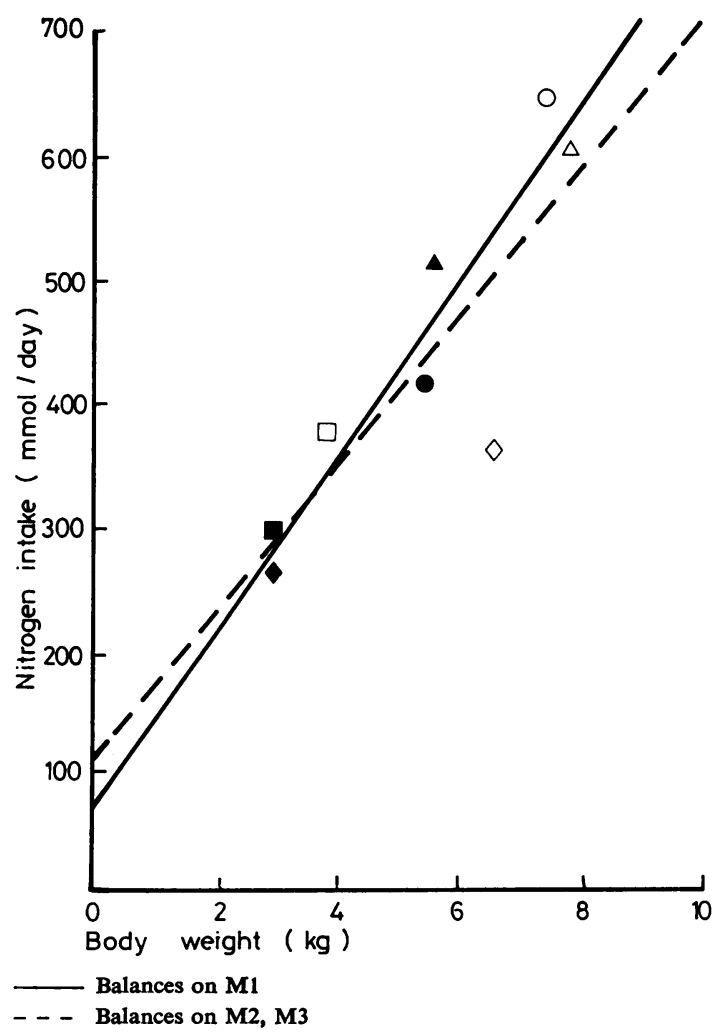

Fig. 7 Daily nitrogen intake v. weight. 


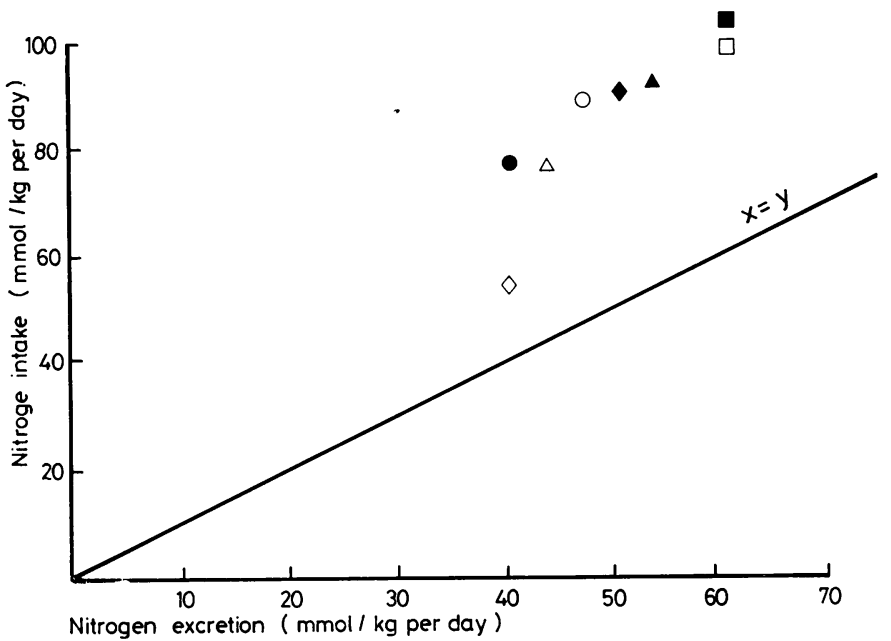

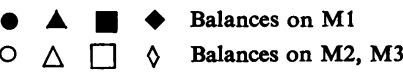

Fig. 8 Daily nitrogen balance. mmol $(1 \cdot 19 \mathrm{~g}) / \mathrm{kg}$ per day on $\mathrm{M} 1$ and $\mathrm{M} 2 / \mathrm{M} 3$ respectively) is much higher on this chicken-based diet than the intake of healthy children, since a higher percentage of the calorie intake is derived from protein. Retentions of $\mathrm{N}$ were 38.9 and 30.9 $\mathrm{mmol}(0.54$ and $0.43 \mathrm{~g}) / \mathrm{kg}$ per day during the 1 st and 2 nd balances respectively (Table 4$)$. These high $\mathrm{N}$ retentions are probably due to the greater than normal growth velocity, or 'catch-up' growth, which was occurring in the children as they attempted to move towards their ideal weights.

Phosphorus. The $\mathbf{P}$ content of M2/M3 remained the same as that of M1. All the children were in positive $P$ balance; mean retentions of 1.35 and $1.51 \mathrm{mmol}$ $(41.9$ and $46.8 \mathrm{mg}) / \mathrm{kg}$ per day were found on M1 and M2/M3 respectively (Table 4 ), and these were equivalent to percentage retentions of $34.1 \%$ (M1) and $38.0 \%(\mathrm{M} 2 / \mathrm{M} 3)$ (Table 6$)$. The mean intakes were $16.9 \mathrm{mmol}(524 \mathrm{mg})$ per day or $3.98 \mathrm{mmol}$ $(123 \mathrm{mg}) / \mathrm{kg}$ per day on $\mathrm{M} 1$ and $23.7 \mathrm{mmol}(735 \mathrm{mg})$ per day or $3.78 \mathrm{mmol}(117 \mathrm{mg}) / \mathrm{kg}$ per day on M2/M3 (Tables 4 and 5). The National Research Council Food and Nutrition Board (1974) recommend $7.7 \mathrm{mmol}(240 \mathrm{mg})$ per day for children under 6 months old, $12.9 \mathrm{mmol}(400 \mathrm{mg})$ per day between 6 and 12 months, and $25.8 \mathrm{mmol}(800$ $\mathrm{mg}$ ) for children over one-year old.

\section{Conclusion}

The mineral and trace metal supplement M1 was inadequate for use with this synthetic diet which contained some natural food. Preparations M2/M3 were satisfactory and M3 was more convenient in use. It should be noted that the comminuted chicken provided about $30 \%$ of the total daily intake of zinc when M2/M3 were used. For children on completely synthetic diets without any natural foods, the intake may not be sufficient even from M2/M3, and the alternative supplements suggested by Alexander et al. (1974) should be considered.

Financial support from the Wellcome Trust, Allen \& Hanburys Ltd, Unigate Foods Ltd, and the Medical Research Council is gratefully acknowledged. The mineral mixtures were kindly provided by Dr P. Woodings of Allen \& Hanburys Ltd.

We are grateful to Dr J. T. Harries for permission to study patients, to $\mathrm{Mr} \mathbf{J}$. Mitchell for technical help, and to the Dietetic Department for assistance in food preparation.

\section{References}

Alexander, F. W., Clayton, B. E., and Delves, H. T. (1974). Mineral and trace-metal balances in children receiving normal and synthetic diets. Quarterly Journal of Medicine, 43, 89-111.

Alexander, F. W., and Delves, H. T. (1972). The preparation of a 'metal-free' nappy and its application to metabolic balances in children. Journal of Clinical Pathology, 25, 927-932.

Cordano, A., Placko, R. P., and Graham, G. G. (1966). Hypocupremia and neutropenia in copper deficiency. Blood, 28, 280-283.

Food and Agriculture Organisation/World Health Organisation (1972). Evaluation of Food Additives. Fifteenth Report of the Joint FAO/WHO Expert Committee on Food Additives. Technical Report Series No. 488. WHO: Geneva.

Larcher, V. F., Shepherd, R., Francis, D. E. M., and Harries, J. T. (1977). Protracted diarrhoea in infancy. Archives of Disease in Childhood, 52, 597-605. 
Lawson, M. S., Clayton, B. E., Delves, H. T., and Mitchell, J. D. (1977). Evaluation of a new mineral and trace metal supplement for use with synthetic diets. Archives of Disease in Childhood, 52, 62-67.

McLeod, B. E., and Robinson, M. F. (1972). Dietary intake of manganese by New Zealand infants during the first 6 months of life. British Journal of Nutrition, 27, 229-232.

National Research Council Food and Nutrition Board (1974). Recommended Dietary Allowances, eighth revised edition. National Academy of Sciences: Washington. van Ravesteyn, A. H. (1944). Metabolism of copper in man. Acta medica Scandinavica, 118, 163-196.

World Health Organisation (1973). Trace Elements in Human Nutrition. UN/WHO Technical Report Series 532. WHO: Geneva.

Correspondence to Dr P. J. Aggett, Department of Chemical Pathology, Institute of Child Health, 30 Guilford Street, London WC1N 1EH. 